\title{
- КУЛЬТУРНО-ДОЗВІЛЛЄВИЙ ТА РЕКРЕАЦІЙНИЙ ПОТЕНЦІАЛ СУЧАСНИХ ГОТЕЛЬНО-РЕСТОРАННИХ КОМПЛЕКСІВ УКРАЇНИ
}

\section{- Даниленко Ольга Вікторівна}

- Кандидат мистецтвознавства,

ORCID: 0000-0002-9245-2957, e-mail: olyadanilenko90@gmail.com, Київський національний університет культури і мистецтв, вул. Є. Коновальця, 36, Київ, Україна, 01133

\section{- Для цитування:}

Даниленко, О.В. (2021). Культурно-дозвіллєвий та рекреаційний потенціал сучасних готельноресторанних комплексів України. Питання культурологіï, (37), 150-158. doi: https://doi. org/10.31866/2410-1311.37.2021.236016.

\section{- Анотація}

Мета статті - окреслити основні аспекти культурно-дозвіллєвого та рекреаційного потенціалу сучасних готельно-ресторанних комплексів в Україні. Методологія дослідження ґрунтується на інклюзивному поєднанні методологічного інструментарію культурологічного, мистецтвознавчого, соціокультурного та структурно-функціонального підходів, а також підходів, інтегрованих із менеджменту. Активно використані загальнонаукові методи пізнання (аналізу, синтезу, спостереження) і принципи (достовірності, системності). Наукова новизна полягає в тому, що в статті розширено уявлення про культурно-дозвіллєвий і рекреаційний потенціал готельно-ресторанних комплексів в сучасній Україні, зокрема на прикладі заміського комплексу «ШишкіNN». Висновки. Конкуренція, значні зміни у вимогах до якості життя, дедалі зростаючі потреби та широкий спектр інтересів людей вимагають від готельно-ресторанних комплексів здатності переорієнтовуватися на надання низки додаткових послуг. Одними з найважливіших складових, яким повинен відповідати сучасний готельно-ресторанний комплекс, є культурно-дозвіллєва і рекреаційна. Для реалізації культурно-дозвіллєвого і рекреаційного потенціалу сучасний готельно-ресторанний комплекс повинен передусім враховувати такі аспекти: особливості архітектурного стилю і забудови; рекреаційне зонування і організацію простору відпочинку; розташування в екологічно привабливому місці; художньо-естетичне вирішення та якісне декоративне оздоблення інтер'єру; проведення різних культурно-дозвіллєвих заходів; спеціальну підготовку керівного і обслуговуючого персоналу тощо. Звернено увагу, що у сучасній Україні при архітектурно-дизайнерському проєктуванні готельно-ресторанних комплексів дотримуються традицій спеціального оформлення та сервісу для максимального забезпечення культурно-дозвіллєвих та рекреаційних потреб відпочиваючих. Про це 
свідчить діяльність таких заміських комплексів, як «Чабани», «Два Бобри», «Козацький Стан», «ШишкіNN».

Ключові слова: готельно-ресторанний комплекс; культурно-дозвіллєва діяльність; рекреація; відпочинок; потреби

\section{Вступ}

На відновлення фізичних, психоемоційних і когнітивно-інтелектуальних сил людині потрібна певна кількість часу. Цей час не може передбачати тільки період сну, а й має включати період, коли людина займається певною діяльністю, що не пов'язана з її професійною роботою. Так, відома формула розрахунку норми робочого часу виходила з принципу: 8 годин - на сон, 8 - на роботу, 8 - на відпочинок. Своєю чергою продуктивність робочого часу безпосередньо залежить від відновлювально-рекреаційної діяльності людини. Адже без сну людина не може існувати у суто біологічно-фрізіологічному розумінні, водночас як істота суспільна вона повинна ефективно використовувати частину неробочого часу, вільного від основної професійної діяльності, саме в рекреаційному напрямі.

Комфортні умови побуту та відповідна сфера обслуговування не можуть повною мірою їх забезпечити, тому так важливо знаходити інші засоби і сфери для відновлення своєї фрізичної та інтелектуальної активності. Саме таким «помічником» у відновленні може стати період, під час якого людина задовольняє свої соціальні потреби, зокрема пов'язані з культурно-дозвіллєвою діяльністю. Традиційно таке завдання було покладено на заклади культури і спорту, однак останнім часом низка комплексів готельного і ресторанного сервісу розширюють свої послуги, використовуючи культурно-дозвіллєвий і рекреаційний потенціал. Тому вивчення культурно-дозвіллєвих можливостей та рекреаційної діяльності останніх - один з перспективних напрямів дослідження сучасної науки, зокрема культурології.

На сьогодні масив досліджень, які стосуються готельно-ресторанних комплексів, умовно можна розділити на декілька напрямів: одні науковці орієнтуються на вивчення організаційних моментів готельного та ресторанного господарювання (Г. Мунін (2002), В. Архіпов, В. Русавська (2012)). Проте інші більше уваги приділяють культурно-дозвіллєвим і мистецько-дизайнерським аспектам їх облаштування. Останні напрями досліджень дедалі частіше зустрічаються у працях дослідників, зокрема українських. Так, О. Савкіна (2012) досліджує рекреаційний потенціал готельних комплексів на прикладі закладів, які фрункціонують під Москвою, А. Кривенко (2019) - особливості готельного господарювання в рекреаційних регіонах. Дизайн інтер'єрів та художньо-естетичне середовище готельно-ресторанних комплексів України досліджують у дисертаційних роботах українські культурологи - автор статті О. Даниленко (2017) та Я. Дьяченко (2016).

Проте в українській культурології не вистачає комплексних досліджень культурно-дозвіллєвого та рекреаційного потенціалу готельно-ресторанних комплексів, що й актуалізує їх дослідження. 


\section{Мета статті}

Мета статті - окреслити основні аспекти культурно-дозвіллєвого та рекреаційного потенціалу сучасних готельно-ресторанних комплексів в Україні. Методологія дослідження ґрунтується на інклюзивному поєднанні методологічного інструментарію культурологічного, мистецтвознавчого, соціокультурного та структурно-фрункціонального підходів, а також підходів, інтегрованих із менеджменту. Активно використані загальнонаукові методи пізнання (аналізу, синтезу, спостереження) і принципи (достовірності, системності). Наукова новизна полягає в розширенні уявлення про культурно-дозвіллєвий і рекреаційний потенціал готельно-ресторанних комплексів у сучасній Україні, зокрема на прикладі заміського комплексу «ШишкіNN».

\section{- Виклад матеріалу дослідження}

Будь-який готельно-ресторанний комплекс відповідно до функціонального призначення, заявленого в його статуті, насамперед має забезпечити гостю комфрортні умови для проживання та якісного харчування. Однак з плином часу вимоги до готельно-ресторанних комплексів розширюються: конкуренція, значні зміни у вимогах до якості життя, дедалі зростаючі потреби та широкий спектр інтересів людей очікують від таких комплексів здатності переорієнтовуватися на надання низки додаткових послуг. Зрозуміло, що нині при спорудженні готельно-ресторанних комплексів одразу керуються такими принципами: органічне облаштування будівлі у навколишньому середовищі; врахування природнокліматичних умов; проєктування рекламного забезпечення; планування раціональної організації обслуговування та відповідного комфорту для проживаючих; відповідність функціональним вимогам та естетико-технічним, санітарним, екологічним нормам тощо (Мунін, 2002).

Одними з найважливіших складових, яким повинен відповідати сучасний готельно-ресторанний комплекс, є культурно-дозвіллєва і рекреаційна.

Рекреація - найважливіша потреба сучасної людини, яка вимушена жити й працювати в надшвидкому темпі у середовищі, яке саме динамічно змінюється. «Здатність ефективно працювати і також швидко й ефективно відновлювати витрачені на роботу сили - це особливість сучасної ділової людини» (Савкина, 2012).

Зазвичай рекреацію більше пов'язують з туризмом і санаторно-курортним лікуванням. Однак на тлі низки чинників, про які йшлося вище, будь-який готельноресторанний комплекс повинен володіти рекреаційним і культурно-дозвіллєвим потенціалом.

На культурно-дозвіллєвий і рекреаційний потенціал готельно-ресторанних комплексів визначально впливає низка чинників. По-перше, потрібно вказати на особливості архітектурного стилю і забудови готельно-ресторанних комплексів, акцентуючи на культурно-дозвіллєвій та рекреаційній складовій їхніх послуг. Так, наприкінці 20-х років XX ст. найбільшу популярність у Європі, на американському контенті та у Японії здобув стиль «фрункціоналізм» або «інтернаціональний стиль». Вимоги до цього стилю торкалися насамперед житлових комплексів, але деякі його особливості стосуються можливості за його допомогою втілити основні ідеї для відпочинку та рекреації. 
У 1928 р. в Афрінах на конгресі міжнародної організації архітекторів СІАМ запропоновано Афрінську хартію, в якій сонячне світло, зелені насадження, свіже повітря і простір було визначено як основні у забудові. Також наголошувалося на необхідності врахування спортивної, рекреаційної і культурно-дозвіллєвої складової, що передбачало заклади громадського харчування, спортивні та ігрові майданчики, бігові доріжки тощо. В Афрінській хартії було закладено поняття «простір для відпочинку», визначено особливості розміщення та функціонального призначення території для відпочинку. Програма відпочинку, розроблена в Афрінській хартії, включала різноманітні заходи і спеціальні споруди: організацію колективних та індивідуальних прогулянок у мальовничих місцях, різних видів спорту і видовищ тощо (Studwood.ru., б.г.).

Дослідники наголошують, що в сучасних готелях зазвичай передбачається зона культурних та спортивно-рекреаційних приміщень. Готелі, що мають рекреаційну зону та високий рівень комфорту потрібно розташовувати у найбільш сприятливих ландшафтних умовах (прибережні або лісові ділянки), що ізольовані від шуму (транспортні магістралі, розважальні центри, спортивні зони) (Кривенко, 2019).

Окрім розташування та організації «простору відпочинку» сучасні готельноресторанні комплекси велику увагу приділяють художньо-естетичному вирішенню своїх інтер'єрів та декоративному оздобленню за допомогою фрункціонального зонування, без якого неможливо задовольнити різноманітні потреби гостей. Також у популярних закладах велика увага приділяється зручним, презентабельним і респектабельним меблям, посуду тощо. Якщо йдеться про зону для розваг, то вона не просто виокремлюється, а й «обігрується» певним декоративним вирішенням, характерним як-то для танцювального майданчика, місця для кальяну, барної стійки та ін. Так, одночасно поєднуються і вимоги до психоемоційної релаксації та функціонального зонування закладу з культурнодозвіллєвою і рекреаційною складовою. «Структуризація різноманіття фрункцій, характерних для сучасних ресторанних закладів XXI ст., зводиться переважно до взаємозв'язку функції харчування з різноманітними елементами дозвілля. У кожному конкретному прикладі здійснюється спроба адекватного архітектурно-художнього вирішення інтер'єру за допомогою комплексної організації простору і функціонального зонування» (Дьяченко, 2016, с. 131-132).

Іншою культурно-дозвіллєвою і рекреаційною складовою сучасного готельноресторанного комплексу є розширення сфрери послуг, які вони надають. 3 одного боку, будь-який готельно-ресторанний комплекс автоматично стає складовою індустрії дозвілля, розваг та рекреації, а з іншого - залишається сферою обслуговування, яка повинна володіти гнучкою системою з метою вираховування різноманітних потреб відпочиваючих, зокрема у культурному дозвіллі.

Вже наприкінці $70-x$ - на початку $80-x$ років XX ст. готельні компанії почали цікавитися поглибленням сегментації готельного ринку, пропонуючи дедалі ширший спектр послуг для забезпечення культурно-дозвіллєвих потреб клієнтів. Готелі не обмежувалися простою функцією надання комфортного тимчасового житла клієнтам, а й стали задовольняти їх потреби у відпочинку і розвагах. 
Багато хто практикував ігорний бізнес, цікавився промисловим приготуванням їжі, намагався зайнятися рекламною діяльністю. Стали популярними готелі типу «апартамент», а також так звані кондотелі, активне будівництво яких пов'язане з виникненням такої форми нерухомої власності, як «кондомініум» (Даниленко, 2017). Згодом особливою популярністю почали користуватися комплекси, на території яких чи поряд можна було б порибалити чи зайнятися полюванням, зокрема «тихим» - на гриби чи ягоди.

Зрозуміло, що такий спектр послуг, який пропонують готельно-ресторанні комплекси з культурно-дозвіллєвою і рекреаційною функцією, розширює перелік вимог і до їх керуючого та обслуговуючого персоналу. Останні повинні володіти хоча б мінімальними знаннями, які стосуються рекреаційних послуг та організації дозвілля.

Таке розширення вимог до знань і вмінь обслуговуючого персоналу пов'язане з тим фрактом, що більшість готельно-ресторанних комплексів пропонують своїм відпочиваючим організацію різних святкових заходів - від дитячих свят, ювілеїв до весіль, випускних та тематичних вечорів і дискотек. Часто комплекси запрошують зіркових гостей - відомих ведучих, співаків, естрадні чи народні колективи. Особливий попит мають різні культурно-дозвіллєві заходи вихідного чи святкового дня з низкою масових гулянь - зустріч Нового року, Різдва, Масляниці, Івана Купала тощо.

Варто наголосити, що в Україні при проєктуванні готельних споруд для досягнення органічного зв'язку зовнішнього й внутрішнього простору традиційно використовували спеціальне оформлення рельєфно-ландшафтного довкілля для максимального забезпечення культурно-дозвіллєвих та рекреаційних потреб відпочиваючих. Цих традицій дотримуються і досі. Зокрема, готельноресторанний комплекс «Чабани» (південне передмістя м. Києва) розташовується серед розкішної української природи, поряд з величезним мальовничим яблуневим садом; приміський комплекс «Два Бобри» (Київська обл.) має альтанки біля озера, піщаний пляж; готельно-ресторанний комплекс «Козацький Стан» розташований на величезній лісовій галявині, серед безлічі сосон; має літній майданчик з альтанками та мангалом, фонтан, композиції ландшафтного дизайну доповнюють територію (Даниленко, 2017, с. 132). Тобто в цих готельноресторанних комплексах реалізуються всі основні завдання Афінської хартії щодо організації простору відпочинку.

Як приклад такого вирішення сьогодні в Україні можна навести досвід рекреаційної та культурно-дозвіллєвої діяльності заміського комплексу «ШишкіNN», який відкрито на території Чернігівської області та який позиціює себе як кисневий курорт для сімейного відпочинку та ділового туризму. Він розташований в затишному сосновому лісі, в якому можна насолодитися природою, співом птахів, свіжістю повітря і приголомшливими інтер'єрами. «До нас їдуть за поєднанням краси природи та комфорту, прогулянками в тиші соснового лісу, пробудженням під спів пташок. Наша територія - це озеро та ліс, стежки та інсталяції, затишні котеджі, комфортні номери та душевні глемпи. Тут чудово відпочивати, грати з дітьми, розслаблятися в SPA, забувши про міські турботи. Тут добре працювати, а в перервах між нарада- 
ми обговорювати як легко думається на природі», - такою змістовною і красномовною є реклама комплексу на офріційному сайті «ШишкіNN» (https://www. shishkinn.com/).

Сучасно обладнані конференц-зали і розвинена інфраструктура допомагають реалізувати загальну концепцію заміського комплексу, що ґрунтується на поєднанні комфорту, активного відпочинку і навіть роботи. В комплексі $€$ всі можливості для проведення корпоративних заходів, семінарів, зустрічей, презентацій, ділових конференцій тощо.

Окрема увага приділена маленьким відвідувачам. Гарно облаштована і безпечна територія, ігрова кімната, дитячий майданчик щонайкраще підходять для різних активностей дітей - ігор та інших розваг. Також їм пропонують спеціальне меню та тематичне проведення вільного часу на свята. Наприклад, на Великдень 2021 р. комплекс підготував триденний анімаційний марафон, який включає квести, творчу майстерню, дитячу дискотеку та караоке.

Для дорослих відвідувачів до Великодня в комплексі передбачено Великий Пасхальний гриль-пікнік, а також конкурсну програму, вечір біля вогнища з веселими музиками та інші культурні заходи для всієї родини.

\section{Висновки}

Отже, для реалізації культурно-дозвіллєвого і рекреаційного потенціалу сучасний готельно-ресторанний комплекс повинен передусім враховувати такі аспекти: особливості архітектурного стилю і забудови; рекреаційне зонування і організацію простору відпочинку; розташування в екологічно привабливому місці; художньо-естетичне вирішення та якісне декоративне оздоблення інтер'єру; проведення різних культурно-дозвіллєвих заходів; спеціальну підготовку керівного і обслуговуючого персоналу тощо.

В сучасній Україні при архітектурно-дизайнерському проєктуванні готельноресторанних комплексів дотримуються традицій спеціального оформлення та сервісу для максимального забезпечення культурно-дозвіллєвих та рекреаційних потреб відпочиваючих. Про це свідчить діяльність таких заміських комплексів, як «Чабани», «Два Бобри», «Козацький Стан», «ШишкіNN».

Дослідження культурно-дозвіллєвого та рекреаційного потенціалу готельноресторанних комплексів проєктується у значно ширшу площину, зокрема щодо організації відповідної освіти підготовки та фахівців у сфері менеджменту соціокультурної діяльності та готельно-ресторанного сервісу. Також уваги потребують приклади організації готельно-ресторанного господарства конкретних комплексів, які функціонують в Україні та за її межами. Це є перспективним напрямом подальших досліджень в даному аспекті.

\section{- Список використаних джерел}

Архіпов, В., \& Русавська, В. (2012). Організація готельного господарства. Центр учбової літератури.

Даниленко, О. В. (2017). Художньо-естетичне середовище готельно-ресторанного комплексу в сучасній Україні [Дисертація кандидата мистецтвознавства, Київський національний університет культури і мистецтв]. 
Дьяченко, Р. В. (2016). Формування дизайну інтер'єрів ресторанних закладів України $X X$ - початку XXI століття [Дисертація кандидата мистецтвознавства, Київський національний університет культури і мистецтв].

Кривенко, А. В. (2019). Рекреаційна зона як об'єкт готельного господарства. В Стратеаічні перспективи туристичної та готельно-ресторанної індустрії в Україні: теорія, практика та інновації розвитку, Матеріали Всеукраїнської науковопрактичної конференції. Україна, Умань, 30-31 жовтня (с. 240-242). Візаві.

Мунін, Г.Б. (2002). Сучасні ефрективні інформаційні технології управління операціями в сучасному готельному комплексі. Формування ринкових відносин в Україні, 16, 34-41.

Савкина, О.В.(2012). Особенности сервиса рекреационных отелей Подмосковья. Сервис в России и за рубежом, 6(33). https://cyberleninka.ru/article/n/osobennostiservisa-rekreatsionnyh-oteley-podmoskovya/viewer

Studwood.ru. (б.г.). Современная рекреационная архитектура. Взято 8 апреля 2021 г. из https://studwood.ru/1649478/nedvizhimost/sovremennaya_rekreatsionnaya_arhitektura.

\section{- References}

Arkhipov, V., \& Rusavska, V. (2012). Orhanizatsiia hotelnoho hospodarstva [Organization of the hotel industry]. Tsentr uchbovoi literatury [in Ukrainian].

Danylenko, O. V. (2017). Khudozhno-estetychne seredovyshche hotelno-restorannoho kompleksu $v$ suchasnii Ukraini [Artistic and aesthetic environment of hotel and restaurant complex in modern Ukraine] [PhD Dissertation, Kyiv National University of Culture and Arts] [in Ukrainian].

Diachenko, R. V. (2016). Formuvannia dyzainu inter'ieriv restorannykh zakladiv Ukrainy XXpochatku XXI stolittia [Formation of interior design of restaurant establishments of Ukraine of the $20^{\text {th }}$ - the beginning of the $21^{\text {st }}$ century] [PhD Dissertation, Kyiv National University of Culture and Arts] [in Ukrainian].

Kryvenko, A. V. (2019). Rekreatsiina zona yak ob'iekt hotelnoho hospodarstva [Recreation area as a hotel facility]. In Stratehichni perspektyvy turystychnoi ta hotelno-restorannoi industrii v Ukraini: teoriia, praktyka ta innovatsii rozvytku [Strategic prospects of the tourism and hotel and restaurant industry in Ukraine: theory, practice and innovation of developmen], Proceedings of the All-Ukrainian scientific-practical conference. Ukraine, Uman, October 30-31 (pp. 240-242). Vizavi [in Ukrainian].

Munin, H. B. (2002). Suchasni efektyvni informatsiini tekhnolohii upravlinnia operatsiiamy v suchasnomu hotelnomu kompleksi [Modern effective information technology operations management in a modern hotel complex]. Market Relations Development in Ukraine, 16, 34-41 [in Ukrainian].

Savkina, O. V. (2012). Osobennosti servisa rekreatsionnykh oteley Podmoskov'ya [Features of the service of recreational hotels near Moscow]. Services in Russia and abroad, 6(33). https://cyberleninka.ru/article/n/osobennosti-servisa-rekreatsionnyh-oteleypodmoskovya/viewer [in Russian].

Studwood.ru. (n.d.). Sovremennaya rekreatsionnaya arkhitektura [Modern recreational architecture]. Retrieved April 8, 2021, from

https://studwood.ru/1649478/nedvizhimost/sovremennaya_rekreatsionnaya_arhitektura [in Russian]. 


\section{CULTURAL, LEISURE AND RECREATIONAL POTENTIAL OF MODERN HOTEL AND RESTAURANT COMPLEXES IN UKRAINE}

\section{- Olha Danylenko}

- PhD in Art Studies, ORCID: 0000-0002-9245-2957, e-mail: olyadanilenko90@gmail.com, Kyiv National University of Culture and Arts, Kyiv, Ukraine

\section{- Abstract}

The purpose of the article is to determine the main aspects of the cultural, leisure and recreational potential of modern hotel and restaurant complexes, in particular in Ukraine. The research methodology is based on an inclusive combination of methodological tools of cultural, art studies, sociocultural, structural and functional approaches, as well as approaches integrated with management. In addition, we have actively used general scientific methods of cognition (analysis, synthesis, observation) and principles (reliability, system, etc.). The scientific novelty lies in the fact that the article broadens the understanding of the cultural, leisure, and recreational potential of hotel and restaurant complexes in contemporary Ukraine, particularly on the example of the ShishkiNN Resort \& Spa country club, Snovianka. Conclusions. Competition, significant changes in the requirements for quality of life, growing needs and a wide range of interests of people require the hotel and restaurant complexes to refocus on providing a number of additional services. Thus, one of the essential components, which must meet the modern hotel and restaurant complex, is cultural and recreational. Consequently, to realize the cultural, leisure and recreational potential, a modern hotel and restaurant complex must, first of all, take into account the following aspects: features of the architectural style and development; recreational zoning and organization of recreation space; location in an ecologically inviting place; artistic and aesthetic solution and high-quality decorative interior decoration; various cultural and leisure events; management and service staff training. Attention is drawn to the fact that there are unique design and service traditions to maximize the cultural, leisure and recreational needs of vacationers in contemporary Ukraine in the architecture and design of hotel and restaurant complexes. This, in particular, is evidenced by the activities of such country house complexes as Chabany, Two Beavers, Kozatskiy Stan, ShishkiNN Resort \& Spa.

Keywords: hotel and restaurant complex; cultural and leisure activities; recreation; rest; needs 


\section{- КУЛЬТУРНО-ДОСУГОВЫЙ И РЕКРЕАЦИОННЫЙ ПОТЕНЦИАЛ СОВРЕМЕННЫХ ГОСТИНИЧНО-РЕСТОРАННЫХ КОМПЛЕКСОВ УКРАИНЫ}

\section{- Даниленко Ольга Викторовна}

- Кандидат искусствоведения, ORCID: 0000-0002-9245-2957, e-mail: olyadanilenko90@gmail.com, Киевский национальный университет культуры и искусств, Киев, Украина

\section{- Аннотация}

Цель статьи - определить основные аспекты культурно-досугового и рекреационного потенциала современных гостинично-ресторанных комплексов в Украине. Методология исследования основана на инклюзивном сочетании методологического инструментария культурологического, искусствоведческого, социокультурного и структурно-функционального подходов, а также подходов, интегрированных из менеджмента. Активно использованы общенаучные методы познания (анализа, синтеза, наблюдения) и принципы (достоверности, системности). Научная новизна заключается в том, что в статье расширено представление о культурно-досуговом и рекреационном потенциале гостинично-ресторанных комплексов в современной Украине, в частности на примере загородного комплекса «ШишкиNN». Выводы. Конкуренция, значительные изменения в требованиях к качеству жизни, возрастающие потребности и широкий спектр интересов людей требуют от гостинично-ресторанных комплексов способности ориентироваться на предоставление ряда дополнительных услуг. Одними из важнейших составляющих, которым должен соответствовать современный гостинично-ресторанный комплекс, являются культурно-досуговая и рекреационная. Для реализации культурно-досугового и рекреационного потенциала современный гостиничноресторанный комплекс должен прежде всего учитывать следующие аспекты: особенности архитектурного стиля и застройки; рекреационное зонирование и организацию пространства отдыха; расположение в экологически привлекательном месте; художественноэстетическое решение и качественная декоративная отделка интерьера; проведение различных культурно-досуговых мероприятий; специальная подготовка руководящего и обслуживающего персонала. Обращено внимание на то, что в современной Украине при архитектурно-дизайнерском проектировании гостинично-ресторанных комплексов придерживаются традиций специального оформления и сервиса для максимального обеспечения культурно-досуговых и рекреационных потребностей отдыхающих. Об этом свидетельствует деятельность таких загородных комплексов, как «Чабаны», «Два Бобра», «Казацкий Стан», «ШишкиNN».

Ключевые слова: гостинично-ресторанный комплекс; культурно-досуговая деятельность; рекреация; отдых; потребности 